\title{
The Emergence of Conversion in a Hindu-Buddhist Polytropy: The Kathmandu Valley, Nepal, c. $1600-1995$
}

\author{
DAVID N. GELLNER
}

University of Oxford

1. Assign as Hindu such as Bahun, Chhetri, Magar, Gurung, Sarki, Damai, etc. who worship the quintile (panchayan) deities, Ganesh, Shiva, Vishnu, Sun and Devi.

2. Followers of Lord Buddha's faith and so inclined religiously are Buddhist such as: Salmi, Udas, Banra [all Newar Buddhist castes], Lama, Thakali, etc.

3. Assign as Islamic believers those reading namaz in the mosque such as Musulman, Churaute, etc.

Note: Where the religion is unclear, assign one of the above religions by inclination of their birth/death customs and behaviours.

-Instructions to the enumerators of the 1952/54 Nepalese census, cited in Gurung (1998:94; 2003:19)

The practice of conversion-changing from one religion to another-is certainly not a modern invention, but it takes on a new and sometimes threatening significance in a modern context characterized by censuses, elections with universal suffrage, and majority rule. In the modern world separate religions have come to be defined, like ethnic groups or nations (Barth 1969), by the boundaries between them. One can only be a refugee if one flees across an international boundary; likewise, conventionally, religious change is only labeled "conversion" if it occurs across a boundary. Thus, as boundaries have become sharper between 'religions,' so the issue of conversion has grown in political significance.

This theme has received considerable attention from scholars of colonial and

Acknowledgments: Final revisions of the paper took place while I was Visiting Professor at the Research Institute for the Study of Languages and Cultures of Asia and Africa (ILCAA), Tokyo University of Foreign Studies (2003-2004), to which I am deeply grateful. I would like to thank John Peel for the invitation that led me to write the first draft of this paper, and seminar audiences in SOAS, Brunel, and ILCAA ('AA-ken') for responses to it. I wish to dedicate it to the memory of Michael Bacharach (1936-2002) who gave me a copy of Ullmann-Margalit's paper (1985). For comments on earlier drafts I thank D. P. Martinez, C. Stewart, W. Tuladhar-Douglas, J. Whelpton, and three anonymous $\mathrm{CSSH}$ reviewers. In simplifying a complex argument, and a still more complex social history, I have not been able to do justice to their many cogent criticisms. 
postcolonial India (van der Veer 1994; Viswanathan 1998; Robinson and Clarke 2003). Whereas in colonial India Hinduism and Islam competed in the public sphere on a footing of formal equality, the relationship between Hinduism and Buddhism in the culturally similar setting of the Kathmandu Valley, Nepal, existed within a very different set of political constraints. Nonetheless, in Nepal, just as in India, an increasingly politicized sense of Hindu identity led to restrictions being placed on conversion, with the key difference that in Nepal the propagation of a political Hinduism came from the state itself.

Anthropological discussions of conversion have been at their most sophisticated and prolonged among Africanists. I think it is fair to say that there is a consensus that Horton's classical theory, despite its admirable focus on context and worldview, and its stress on the actor's point of view, is too individualist (ignoring group conversions) and too intellectualist (ignoring political and economic factors, as well as emotive identity ones). ${ }^{1}$ Discussions of the spread of Hinduism, as far as I know, never link up with the literature on conversion and this could be said to have impoverished both sets of discussions, though some of them have proceeded in parallel, particularly as concerns Muslim reform movements.

Any analysis of the nature of conversion in a given historical context simultaneously requires one to understand the relationship of the dominant types of religion between which religious change is supposed to be taking place. In the context of the Kathmandu Valley it requires one to ask what kinds of things Buddhism and Hinduism are and were in diverse historical contexts, and the question of the boundary between them cannot be separated from the question of what kinds of entity they were conceived to be.

In the past, South Asian religious boundaries were conceived in ways very different from the dominant modern model of one-and-only-one religious identity per individual. If there is no clear boundary, can there be different religions? Michael Carrithers (2000) has coined the felicitous term "polytropy" for what he calls "the natural condition of spiritual cosmopolitanism in India": in the religiously highly diverse world of South Asia, people recognize that there are an enormous number of holy people and sites, all of whom and all of which deserve respectful worship ( $p u j a$ ). Only a few people take the purist line that one should stick to only one kind of religion and/or that performing worship is an inferior path or even downright wrong. In such polytropic religious situations, which, far from being unique to South Asia, are common in Asia as a whole, ${ }^{2}$ it is very hard to divide people up and allocate them unambiguously to discrete religious categories. In this kind of situation religions are not, and cannot be assimilated to, naturally occurring 'medium-sized dry objects'; nor are they dis-

${ }^{1}$ See Horton (1971; 1975), and for critiques see Fisher (1973; 1985), Peel (1977; 1990), IkengaMetuh (1987), Hefner (1993), and Meyer (1996).

${ }^{2}$ I have examined some similarities between Japan and Nepal in this respect in Gellner (2001a: chs. 14 and 15). 
crete boxes into which individuals can be neatly, unambiguously, and uniquely assigned. Nonetheless, census-takers are obliged to try and do precisely this, as indicated in the epigraph given above. ${ }^{3}$

The question of conversion is taken up from the point of view of the philosophy of rational choice by Edna Ullman-Margalit in "Opting: The Case of 'Big' Decisions." She puts forward a series of distinctions between types of decisionmaking and suggests that rational choice theory applies only to "middle-sized" decisions. Trivial choices, as between two pieces of candy about which one is indifferent, she classifies as 'picking'; large, life-changing decisions she designates "opting." Ullmann-Margalit points out that "opting" is similar to "converting" in that both refer to "life-transforming, core-affecting, largely irrevocable" life events. However, unlike "opting" decisions, "In converting it is not the case that one believes that one is called upon to make a genuine decision between equally viable alternatives. From the point of view of the convert he has no choice in the matter ... [Furthermore] typically, for the person who has undergone conversion, his previous life is not just technically rejected. . . but also normatively rejected. The convert views his previous life ... as wrong or wicked" (Ullmann-Margalit 1985:446).

Thus the defining criteria of conversion in this terminology are the experience of compulsion and the rejection of the previous life. Clearly the model here is St. Paul on the road to Damascus, so let us label this kind of conversion 'conversion ${ }_{\mathrm{sp}}$.' Ullmann-Margalit immediately accepts that there are cases of "formal or technical religious conversion" which would count either as "normal" decisions or as "opting," as when Heinrich Heine or Gustav Mahler converted to Christianity, or when Henri IV accepted Catholicism in order to ascend the throne of France. Let us call this kind of conversion, which results in a change of the census category one is assigned to, 'conversion ${ }_{\mathrm{cc}}$.' Clearly there is no necessary connection between these two types of conversion: one can convert $_{\mathrm{cc}}$ without the experience of conversion ${ }_{\mathrm{sp}}$, and one can have the experience of conversion $_{\mathrm{sp}}$ while remaining within a given religious category.

Ullmann-Margalit goes on to discuss the rationality of opting: How can one rationally make a decision which involves assessing and possibly discarding the very criteria of rationality one has accepted up till now? She suggests that one psychological method of dealing with large decisions is to ignore them, so that a series of minor, incremental steps add up to a big decision without it ever having been the object of a big decision, as in drug addiction or someone gradually becoming committed to a career. This type of decision-making she calls "drifting." Summing up her discussion, we can think of all these terms as labeling points on a spectrum, with 'picking' at the trivial end, moving through 'middle-sized' decisions, to 'opting' at the life-changing end. Because it is re-

\footnotetext{
${ }^{3}$ I have argued that Nepal ought to allow multiple responses to census questions on ethnicity and religion in Gellner (2001b; forthcoming).
} 
garded as being in a sense beyond choice, or compulsive, 'conversion ${ }_{\mathrm{sp}}$ ' might be viewed as lying at a tangent to 'opting.' The same might be said for 'drifting,' since it is a way of arriving at either 'middle-sized' or 'large' decisions without any actual decision being made.

The problem with Ullman-Margalit's distinctions, from the point of view of the ethnographic and historical record, is that her definition of 'conversion,' as with so many terms that have entered social scientific vocabulary, is colored by a rather particular Christian set of assumptions, as well as by the modernist assumption of unique and context-free religious allegiance. A recent collection of essays on conversion in India (Robinson and Clarke 2003) describes numerous cases of modern conversion movements in India that were directed primarily at purifying an already existing religious identity (whether Sikh, Muslim, Hindutribal, or Jain). In India only Christian conversion and the conversion of Ambedkar's followers to Buddhism would count conventionally as conversion, because only they led to a change in the census category to which the converts would be assigned. Furthermore, very few of the diverse cases discussed in Robinson and Clarke's book were conversions ${ }_{\mathrm{sp}}$ : most were examples of 'opting' or perhaps even simply 'middle-sized' decisions. In other words, they involved weighing up the social and political advantages to be gained by changing one's ultimate religious allegiance. Ironically, it may well have been in the cases of 'internal conversion' - that is, the adoption of a reformist path within an already existing identity, the deepening and transformation of an already held commitment - that the greatest psychological turmoil occurred.

In short, it may well be that, in terms of Ullmann-Margalit's distinctions, the vast majority of actual conversions in history are or were cases of 'opting' or even just 'drifting,' and not 'conversions sp' at all. Furthermore, as we have seen, at least in India, many were not conversions ${ }_{\mathrm{cc}}$ either. But providing we recognize that conversion ${ }_{\mathrm{sp}}$ and conversion ${ }_{\mathrm{cc}}$ are models and do not confuse them with 'facts on the ground,' this terminology may help to guide us through the tangled web of actual cases. ${ }^{4}$

Thus a striking recent paper by N. J. Allen describes how the Thulung Rai of east Nepal have gradually become Hinduized (adopting Brahman priests and Hindu festivals, interacting with Untouchables in an idiom of Hindu purity). The Thulung Rai are one sub-group of the Rai, who are themselves one of a number of ethnic groups each with their own language and culture, strung out along the Himalayan foothills. In the past they were known as 'tribes'; since 1990 they have been generally known by the neologism "Janajati." Allen concludes that the Thulung "have been experiencing and reacting to a massive historical process in a manner so fragmented and piecemeal that its systematic na-

${ }^{4}$ Brekke (2003), in an examination of the Buddha's early disciples, insists that only conver$\operatorname{sion}_{\mathrm{sp}}$ is conversion. Thus he is able to conclude that when they renounced householder life to become ascetics this was conversion, but when they switched from following Hindu teachers to following the Buddha, it was not. 
ture has not been apparent to them ..." (1997:322). In other words, conversion to Hinduism, or Hinduization, happened to the Thulung by 'drifting.' In recent years activists have attempted to put the process into reverse and have campaigned for Rais to return their religion as "Kiranti" (Gaenszle 1997). The activists are quite deliberately setting out to reverse 'drifting' by means of a (in the main, politically motivated) middle-sized decision.

For those already within the fold of Hinduism there is the process of Sanskritization - the adoption of higher-caste, usually Brahmanical, practiceswhich is not, of course, unconscious. ${ }^{5}$ The classic cases combine the features of 'opting' with the moral evaluation of 'conversion ${ }_{\mathrm{sp}}$ ' (the previous form of life was impure), with some straightforward pragmatic considerations more characteristic of ordinary big decisions. The key point about such forms of Sanskritization is that it is a group decision, one that is supposed to ensure a better future for the group as a whole. In other words, it is a form of religious change of identity that, on several counts, seems to confound the neat typology of action outlined above.

\section{HINDUISM AND BUDDHISM IN MEDIEVAL AND MODERN NEPAL}

Conversions to Buddhism, both group and individual, certainly took place over two millennia ago. When Buddhism arose in the fifth century B.C.E. it was a very different kind of religion from Brahmanism. (I write 'Brahmanism' advisedly, because 'Hindu' as a religious term cannot be found before the fifteenth century, and 'Hinduism' in English was not used before the early nineteenth century. ${ }^{6}$ ) Brahmanism was a worldly, ritualistic, and at times mystical religion, which required the sacrifice of animals. It was based on orally transmitted texts in an archaic Vedic Sanskrit that few understood. It was exclusivist in that only Brahmans or selected high-status others could practice it. Buddhism was one of a number of renouncer religions that rejected all this. Buddhism was-relatively, and certainly when contrasted with Brahmanism-otherworldly, antiritualistic, rationalist, egalitarian, and opposed to sacrifice. It, too, passed on its texts orally, but, unlike the Brahmans', the Buddhist texts were redacted in the vernacular, which only turned into a scriptural language remote from ordinary speech through the passage of time (Gombrich 1988).

Two thousand years later, in the Kathmandu Valley, not far away from Buddhism's point of origin, both Brahmanism and Buddhism had changed enormously. Brahmanism had evolved by absorbing the soteriological message of the renouncer religions ${ }^{7}$ : it was now defined, like Buddhism, as a marga or

5 The term was coined by Srinivas in 1952: see his discussion in Srinivas (1956). See also Staal (1963).

6 See Flood (2003:3), and also von Stietencron (1997), Lorenzen (1999), and Michaels (2004:13ff).

7 The best introduction to this process, though no more than an introduction, is still Dumont's classic essay on world renunciation (1960). 
'way,' but in this case as the way of Shiva. Brahmans now tried to keep their distance from animal sacrifice. Buddhism, on the other hand, had become highly ritualistic, possessed a caste of hereditary priests very similar to Brahmans, and now had its own scriptures (the Mahayana Sutras and the Tantras) in the Brahmans' holy language, Sanskrit. What Hinduism and Buddhism have in common is, in many cases, underpinned by a shared basis in Tantrism. ${ }^{8}$ The term Hinduism itself covers very different, and sometimes conflictual, religious streams, especially Vaishnavism and Shaivism, the more Tantric forms of the latter often being identified as a third, distinct current, namely Shaktism or the cult of the Tantric Goddess. Despite these differences, religious identity was primarily inherited and group-oriented. One was either a buddhamargi, a follower of the path of the Buddha, or a shivamargi, a follower of the path of Shiva, and this was determined by whether one's household traditionally made use of a Buddhist Vajracharya domestic priest or a Brahman one. But since each priest provided the same range of rituals (with the sole exception that Brahmans delegated the post-mortem purifying grhasuddhi rite to lower-ranking Shaivite Karmacharya priests) lay people often regarded them as essentially substitutable the one for the other. Individuals might have preferences for one particular god or form of religion, but as long as they continued to participate in the household's traditional rites, this was no one's affair but their own. In the nineteenth century and after, cases of switching from one kind of priest to another occurred only in the Buddhist to Hindu direction. This was definitely not a case of conversion $_{\mathrm{sp}}$, but rather conversion ${ }_{\mathrm{cc}}$ for reasons of social climbing, and is discussed further below.

For ease of exposition it is worth distinguishing four periods, as shown in Table 1. Such periodizations are heuristic devices: many of the trends or forms that I shall discuss overlap periods, and many forms of ritual practice have continued through all of them. Nonetheless, the different political regimes have definite implications. What we are looking at, in investigating relations between the two most salient religious traditions, is the relation between Buddhists and Hindus. This frequently had to do with political competition between high castes. But it also had to do with Buddhists' relations with the King, who in all four of these periods was, and had to be, Hindu, and with the state. ${ }^{9}$ Simplifying greatly, one can say that in the first two periods it was assumed that the two religions were essentially the same kind of thing, and that they were unequal (whatever differences of opinion there might be about which was superior), and that therefore one of them could be seen as an included and inferior part of the other. At the very end of the second period, the notion that Buddhism

8 On Tantric Buddhism in Nepal, see Gellner (1992) and Lewis (2000); on Tantric Hinduism, see Levy (1990).

9 That the King was always Hindu was true also of the earlier period, $750-1482$, covered by Petech (1984:203). 
TABLE 1

Periods of Recent Napalese History

\begin{tabular}{|c|c|c|}
\hline Period & Polity & Ideology \\
\hline $\begin{array}{l}\text { Malla } \\
\qquad(1200-1769)\end{array}$ & petty kingdoms & $\begin{array}{l}\text { theater state supporting all established } \\
\text { cults, with a strong Hindu bias as far as } \\
\text { the King's personal position was } \\
\text { concerned }\end{array}$ \\
\hline $\begin{array}{l}\text { Shah/Rana } \\
\quad(1769-1951) \\
\text { Pop } 1911: \\
\text { 5.6 million }\end{array}$ & $\begin{array}{l}\text { patrimonial, strong } \\
\text { hereditary prime } \\
\text { ministers, weak } \\
\text { kings }\end{array}$ & $\begin{array}{l}\text { authoritarian and autocratic, strongly } \\
\text { Hindu (other religions only permitted } \\
\text { when traditional), supporters of British } \\
\text { Raj while minimizing foreign influences }\end{array}$ \\
\hline $\begin{array}{l}\text { Panchayat } \\
\text { (1960-1990) } \\
\text { Pop } 1960: \\
\text { c. } 9.4 \text { million } \\
\text { Pop } 1990: \\
\text { c. } 18.5 \text { million }\end{array}$ & $\begin{array}{l}\text { guided, partyless } \\
\text { democracy }\end{array}$ & $\begin{array}{l}\text { developmentalist, nation-building } \\
\text { (i.e., ethnic languages and cultures } \\
\text { discouraged), authoritarian, political } \\
\text { parties and proselytization banned } \\
\text { Hinduism as official religion }\end{array}$ \\
\hline $\begin{array}{l}\text { Multiparty } \\
\text { (1990-2002) } \\
\text { Pop } 2004: \\
\text { c. } 23 \text { million }\end{array}$ & $\begin{array}{c}\text { constitutional } \\
\text { monarchy }\end{array}$ & $\begin{array}{l}\text { developmentalist, liberal, hesitant moves } \\
\text { toward multiculturalism. Constitution } \\
\text { still bans proselytizing and defines } \\
\text { Nepal as a Hindu Kingdom, but reli- } \\
\text { giously free in practice }\end{array}$ \\
\hline
\end{tabular}

and Hinduism were essentially different, and therefore ought to be treated separately and equally, was introduced from abroad and gained increasing ground. By the time of the framing of the new Constitution in 1990 it was a major cause for controversy that religious equality was explicitly granted but that Nepal continued at the same time to be designated as a Hindu kingdom - in stark contrast to the fact that the new and unprecedented labels 'multi-lingual' and 'multiethnic' were introduced. Simplifying even more grossly, one can say that a basically hierarchical notion of religion has gradually, but still not completely, given way to an egalitarian one.

During the four periods to be considered, Buddhism and Hinduism did not exhaust the religious field in Nepal. From the beginning of the eighteenth century there were Christian missionaries active in the Kathmandu, until they were sent packing by Prithvi Narayan Shah in 1769. There were Muslims in the Kathmandu from at least a century before this. Many tribal traditions also existed, though being non-literate they were not valued as highly. There was a tendency, especially in the Rana and Panchayat periods, to see them as subordinate forms of Hinduism. The introduction of decennial censuses in the 1950s marked the beginning of the end for contextually shifting identities (Table 2). 


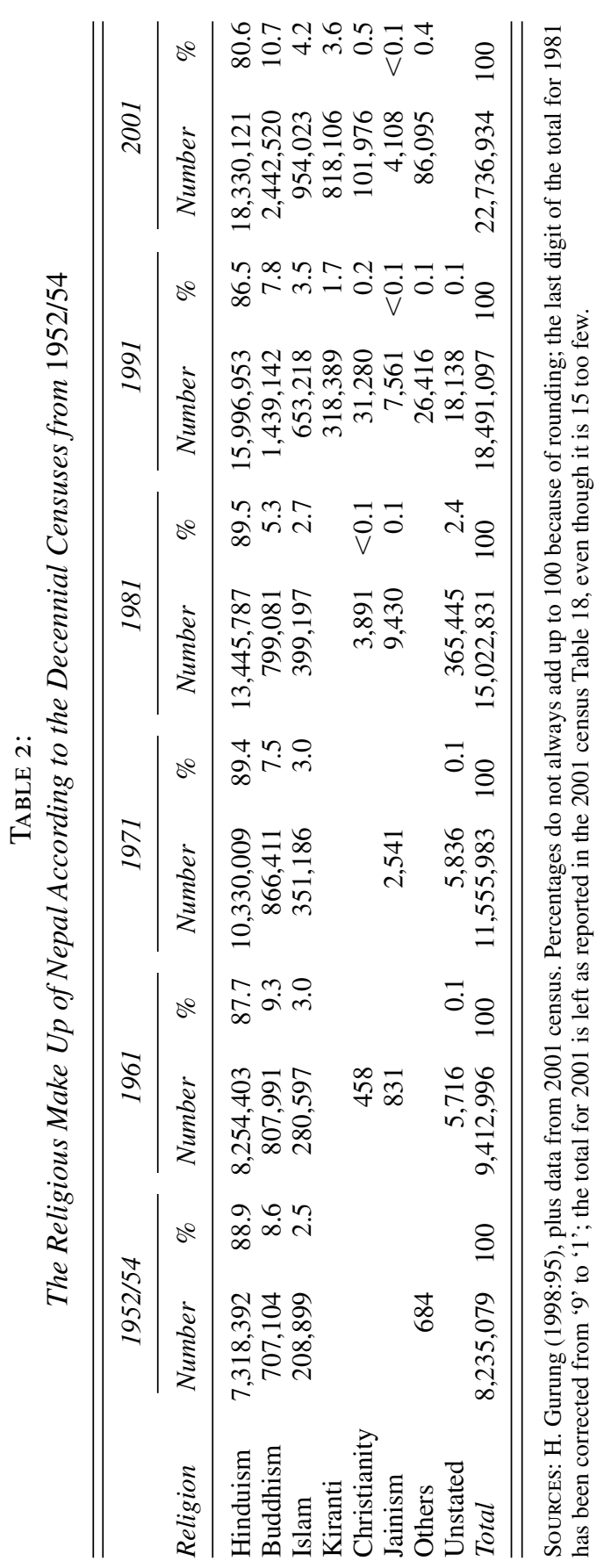


THE LATER MALLA PERIOD (1600-1769)

There were three royal cities in the Kathmandu Valley in the Malla period: Kathmandu itself, Lalitpur (Patan), and Bhaktapur. To simplify I shall focus on Lalitpur. Much of what is said here will apply to Kathmandu as well, which also had a very strong, though perhaps not so numerically dominant, Buddhist population. There are and were many fewer Buddhists in Bhaktapur and it is today much more strongly and univocally Hindu than either Kathmandu or Lalitpur. Of the three cities, the contrast between the Hindu king and the Buddhist population was sharpest in Lalitpur. It therefore illustrates most strikingly the ways in which the two identities could exist in a polytropic universe where religious differences were marked but conversion had very little salience.

In the Malla period, as today, Lalitpur had a two-fold elite: Buddhist high castes - Vajracharyas and Shakyas - and Hindus, known generically as Shresthas. Today these two groups are clearly in opposition in local elections, and, at least in the old city, the Shresthas are simply not numerous enough to win. The Maharjans, the middle-ranking peasant caste, are the most numerous of all; although the Mayor of the town has always been a Shakya or a Vajracharya, Maharjans have provided many other representatives, both Communist and Congress, as well as the local Member of Parliament. ${ }^{10}$

It would be a mistake to project this local opposition of Hindu to Buddhist high castes back into the history of Lalitpur in any simple-minded way. We know that in the eighteenth and even into the nineteenth century many of the ancestors of those who today count as Hindu Shresthas had Buddhist priests and Buddhist allegiances. What is not in doubt, however, is that the very apex of the social hierarchy in the Malla period was expected to be Hindu. The king's palace at the center of the city was surrounded by temples of Shiva and Vishnu. The kings claimed to be descended from Rama and to be an incarnation of Vishnu. Inside the palace were the shrines of his personal divinities, Taleju, Degutale, and Dwimaju (all forms of each other and of Durga), and these were served by Brahman and by Shaivite Karmacharya priests (Toffin 1993). There is no Buddhist shrine either in the palace or in the royal square in front of it. So in 1973 the organizing committee of the annual Buddha Jayanti festival established a Buddha statue among all the Hindu temples and named the site Vishvamaitri Vihara.

The complicated relationship of Buddhist subjects and their Hindu king in the city-state of Lalitpur during the later Malla period can be illustrated by the cult of Karunamaya/Matsyendranath, who was and remains the most important popular god of the city and its surrounding villages. Colloquially he is known as Bungadyah ('the god of [the village] Bunga'). To Buddhists he is usually known as Karunamaya ('embodiment of compassion'), an epithet of the bodhi-

\footnotetext{
10 On Newar castes, see Toffin (1984) and Gellner and Quigley (1995). On the sacred geography of Lalitpur, see Gutschow (1982).
} 
sattva Avalokiteshvara. Hindus and the wider world tend to know the god as Matsyendranath or Macchendranath ('Lord of fishes' or 'Lord who took the form of a fish'). This latter name and the legends that go with it became current only in the seventeenth century at the time when it was necessary to have an explicitly Hindu rationale for participation in the god's cult. ${ }^{11}$ We know that the cult of Avalokiteshvara in the village of Bunga existed already in the tenth century, and probably goes back several hundred years before that. However, in the seventeenth century the two great rulers of Lalitpur, Siddhi Narasingh (reigned 1619-1660) and his son Sri Nivas (reigned 1660-1684), were seeking to bring Lalitpur out from the shadow of Kathmandu and, despite their own Shaivite and Shakta practices, sponsored the cult of Bungadyah in a big way, making him the protector of the whole city. Simultaneously they encouraged his identification with the Shaivite saint Matsyendranath. This included building a second temple for him within the city, so that henceforth he would spend half the year in the city of Lalitpur, and half in his original home in Bunga (his priests are always from Bunga and travel with him). ${ }^{12}$

Still today the god is the most important in the city for all castes, for both Hindus and Buddhists. His festival is the city's biggest, observed by everyone. He is particularly popular with the largest caste, the Farmers, and he is believed to bring the annual rains on which their crops depend. In the widely known myth of King Narendradeva fetching him from Assam, the point of bringing him is that only he can stop a twelve-year drought. In the popular telling of the myth by Asha Kaji Vajracharya (1980), which has gone through five or six printings, it is Vishnu who gives the rice plant, but only Avalokiteshvara can ensure that there is grain inside the husks.

In this version of the origin story, it is obvious that the journey to Assam to fetch the god is a sacrificial metaphor. There are three who go on the journey: the king Narendradeva, from Bhaktapur, the Vajracharya priest, Bandhudatta, from Kathmandu, and the Farmer bearer, Rathanchakra, from Lalitpur. It is only through their joint efforts that they manage to bring Karunamaya back from Assam. However it is recognized that the king, as sponsor, had the right to establish the god in his city, Bhaktapur. But by a trick, it ends up in Lalitpur.

The myth expresses one important model of the relation of king to priest and

11 The principal sources are Locke (1980), Owens (1989; 2000), Toffin (1993), and Douglas (2002). Such conflations of Buddhist bodhisattvas and local divinities were standard in pre-Meiji Japan (Grapard 1992).

12 See Locke (1980:333-34) and Gellner (1996:139-40) for discussions of the evidence for the dating of this. There is no need to doubt, as Toffin does (1993:144 fn. 21, $153 \mathrm{fn}$. 48), that references to Matsyendranath do indeed refer to the Avalokiteshvara of Bunga or that the temple in Lalitpur was indeed constructed in the seventeenth century. Siddhi Narasingh was also prepared to interfere in the internal organization of the Buddhist Sangha (which by then had become a married and hereditary institution) and to insist on the performance of Hindu death rituals (see Gellner 1996:142-48; 2001a:162-64). 
laity: the King as the patron (yajamana, jajman) of the sacrifice acts on behalf of the people and the country. It is, of course, a very Hindu model, but it is one that can be made compatible with Buddhist ways of expression by translating 'sacrificer' into guru and sacrifier (jajman) into disciple (cela). As long as this second model could coexist with the Hindu one, Vajracharyas were happy to use Hindu terminology when it was politic and advantageous to do so (Gellner 1992:139-42).

A second model is that of the king as bodhisattva. There is not so much evidence of this, but there are some examples. In the first place, Buddhist ritual clearly encourages the view that Vishnu is a bodhisattva (Gellner 1992:82, 225), and the king is a form of Vishnu. Second, the famous golden window of the palace in Lalitpur shows a form of Avalokiteshvara emitting all the gods, with the symbols of Vishnu above and below. This again identifies a bodhisattva with Vishnu and with the king. When the king sat at the window the identification was no doubt made, and meant to be made, all the more obvious. The king acted out the role of Vishnu once a year in the climax to the annual dance performances of the month of Kartik, when he took the part of Narasimha to kill the demon Hiranyakashipu. There is no such ritual in which he was identified with Avalokiteshvara.

\section{Christian Missions in the Kathmandu Valley}

Into this world of competing but compatible religious traditions, Christian missionaries entered, passing through in the seventeenth century and settling and working in the eighteenth. Over a period of fifty-four years (1715-1769) a total of twenty-nine Capuchin fathers worked in the three city-states of the Kathmandu Valley. Sometimes they were regarded with suspicion, but mostly they seem to have been welcomed and at times the kings of the Valley sought them out, invited them to Nepal, and vied with each other to have them in their kingdoms. Ian Alsop has written fascinatingly about the text that one of them, Padre Vito da Recanati, composed in the local vernacular, Nepal Bhasha (Newari), in 1740, with the help of a local Brahman, Balgovinda, in order to refute the local religions and convince Ranjit Malla, the King of Bhaktapur, of the truth of monotheism. The King's Brahman preceptor, Kashinatha, "was thrown into confusion, mumbling lamely that he would have the book sent to Kasi [Banaras] for a thorough examination, and later challenging the padres to a trial of magic at which he said he would prove the superiority of his religion by 'being able to fly in front of all the people.' Later he calmed down somewhat and in a friendly discussion with P. Vito and the Prefetto resolved some of their differences, insisting that both religions had the same basic concepts" (Alsop 1996:13334). Despite all their efforts over many years, none of the palace courtiers were willing to convert, but the King offered the Capuchin fathers some of his people to be their pupils. This they refused, saying that they only wanted those who came to them of their own free will (Alsop 1996:132). 


\section{The Malla Period: Multivocality, Polytropy, and Religion as Hereditary Group Identity}

During the Malla period Hindu kings gave considerable support to Buddhist festivals and Buddhist rituals. The elite of Lalitpur was largely Buddhist and supported Buddhist festivals, rituals, and priests even more strongly than in the other two cities. Yet the King's own personal religiosity was always Hindu and looked to Indian models. Brahmans had the highest status as priests and they were reserved for the king and those closest to him in status. Some high-ranking Shresthas had Brahman domestic priests, but kept Buddhist Vajracharyas as their priest for Tantric initiation (diksa-guru). The kings of Lalitpur were happy to support the cult of the bodhisattva Karunamaya, and encouraged identifications of it with Hindu gods. They treated it as the top local cult that had to be gradually molded to Sanskritic, Hindu norms. Religions were identified with groups. If an individual chose, as a matter of personal preference, to support a different cult, that had no implications for conversion, providing group obligations were maintained. Only a Hindu becoming a Buddhist monk would count as complete conversion in this period and there are no records of this occurring. The encounter between the Capuchins and the king's Brahman is revealing in that Kashinatha both challenges the missionaries to a competition in order to prove that he is better and at the same time ends by insisting that both religions are ultimately the same. These two discourses are precisely those that prevail still today between traditional Newar Buddhism and Hinduism.

Whether this attitude deserves to be called 'religious tolerance' is a controversial matter. ${ }^{13}$ Although the Malla kings were frequently very welcoming to the Capuchin missionaries, there does not seem to have been any real chance of the kings converting. In 1767 the Briton Kinloch led an abortive and disastrous expedition towards Kathmandu to assist the Malla kings in their last stand against Prithvi Narayan Shah. Prithvi Narayan decided that the Capuchins must have invited the British in and forced them to leave Nepal. They took fifty-nine converts with them, who settled just over the border in Bettiah. Christian missionaries did not return for nearly 200 years. With a powerful new Christian neighbor to the south, the Shah and Rana rulers never wished to risk a fifth column on their territory.

\section{AFTER THE GORKHALI CONQUEST}

Prithvi Narayan Shah's conquest of 1769 brought about an entirely new situation. Instead of a large number of small kingdoms, there was one kingdom of Nepal, pretty much as it is today. Much land belonging to Newars was confiscated in the Valley kingdoms. Many Newars emigrated to the hills, both in search of trading opportunities (whether as merchants or artisans) and to escape punishment for associations with the previous regime. The new ruling class spoke a

13 See Brinkhaus (1996), Höfer (1979:164-65), and Halbfass (1988:ch. 22). 
different language (Nepali, then known Gorkhali, Khas Kura, or Parbatiya), had different Brahman priests, and brought with them many new settlers in the Valley. For the elite Newar priestly families who did stay behind, it was essential to establish the legitimacy of their traditions and their landholdings. As Sylvain Lévi (1905 I:196) pointed out over a century ago, this explains the sudden rash of historical chronicles (vamsavali) written in Nepali, the conqueror's language, in order to explain, justify, and protect the local traditions, both religious and those to do with caste, and the endowments which supported them.

The Rana regime was inaugurated when Jang Bahadur Rana seized power following the infamous Kot massacre of 1846. Thereafter the kings of Nepal were reduced to puppets, as in Tokugawa Japan, and the effective rulers were the descendants of Jang Bahadur. The Ranas' rule was autocratic and patrimonial. Its religious policy was one of strong Hinduization and the exclusion of foreign influences, including education and Christianity. Traditional customs were supported by the law, which was codified systematically for the first time in the Muluki Ain, or national legal code of $1854 .{ }^{14}$ All subjects were expected to observe the ban on cow slaughter (though those who had a tradition of eating beef could still consume carrion: Michaels 1997) and to participate in the national festival of Dasain. Local elites were encouraged to imitate the Hindu customs of the rulers, a form of Sanskritization that did, in practice, involve conversion for some Nepalis. For example, the Thakali traders of west Nepal switched their primary allegiance from Tibetan Buddhism to Hinduism at this time, as did certain high-status Gurung lineages. ${ }^{15}$ In the Kathmandu Valley many Shresthas who traditionally had Vajracharya domestic priests switched from them to Brahmans and adopted forms of Hinduism closer to those of the now dominant Parbatiyas - a practice recognized in the Nepali proverb, jasko sakti, usko bhakti ('whose power, his devotion,' that is, people tend to adopt the religious forms preferred by rulers). ${ }^{16}$

There was in effect a legally sanctioned hierarchy of religions, with Hinduism at the top, Buddhism as practiced by Newars (i.e., including caste purity practices, avoidance of pork and beef, etc.) ranking in the middle, and Islam and Tibetan Buddhism being very low-ranking indeed, mainly because of their consumption of beef and their indifference to Hindu interpretations of purity. ${ }^{17}$ Non-Hindu religions were tolerated providing they were established as the traditional religions of specific groups.

The Ranas' stress on Hinduism meant that it became harder to practice the easy ambiguity of multivalent symbolisms (Carrithers' polytropy) than it had

14 On the Muluki Ain, see Höfer (1979). On the early Rana period see Whelpton (1991).

15 On the Thakalis, see Fisher (2001). On the Gurungs who competed with them for control of the salt trade, see Messerschmidt and Gurung (1974).

16 On this process, see Rosser (1966), and the critique by Quigley (1996). An alternative interpretation of the proverb is: 'People tend to worship those who hold power.'

17 Yaks count as cows, though they are distinguished from them (Michaels 1997:91-92). 
been before, particularly for high-status Newars in the capital. Conversion came to be seen as a real possibility and as a threat to the social order. Höfer explains that in the 1854 national code: "Traditional religion cannot be abandoned ... [T] he conversion of Hindus to other religions is explicitly prohibited, whereas, vice versa, the conversion of Buddhists or atheists to Hinduism is not. The followers of religions other than Hinduism are only protected against intolerant behaviour and thus against coerced conversion. In this way, the MA sanctions the confessional status quo, not without leaving Hinduism the chance of being propagated by diffusion as a popular or national religion, indeed, as the dharma per se" (1979:158).

Traditions of the Malla period were maintained under the Ranas because 'tradition' was highly valued. In the face of an autocratic government, 'tradition' was the best defense against pressures to conform and to Hinduize. This was well illustrated by their reaction to Mahapragya becoming a Buddhist monk in 1925. He was born Prem Bahadur Khyahju and, according to his autobiography, he had a series of intense spiritual experiences, rather like conversion ${ }_{\mathrm{sp}}$, which led him to become a monk. He was initiated along with four other young Newar men. Becoming a Tibetan monk might have been acceptable in Mahapragya's four companions, because they came from traditionally Buddhist families, but Mahapragya was a Shrestha, therefore a Hindu by birth. The Ranas expelled all five from the country, along with the Tibetan lama who had initiated them, in 1926.

In his autobiography Mahapragya recalls an incident that occurred in one of the Ranas' palaces before the expulsion:

Mauni Baba [a Hindu fakir] sat on the mattress and asked about me: "Who is that sitting over there in window?" The Colonel said, "He is a great soul (mahatma), like you. He has come here to get permission from the Prime Minister to stay on Mount Nagarjun." Then the learned Brahmans assembled there said: "How can that man be a great soul? Can you be a great soul by abandoning your own dharma?" Looking at me, he then said, "You [impolite form] why did you [leave off] your own dharma for that of others? You are not allowed to take up others' dharma. Your own flesh and blood are sivamargi [followers of the path of Shiva], you are not from a Buddhist caste, you have to accept the dharma of Shiva." I said, "It is not the case that I left off my own dharma for that of others." They said, "How can you say you did not? Did you not give up the dharma of Shiva and take up that of the Buddha?" I said, "There is only one dharma in the world, not two or three. It is only you who divide dharma up into different kinds. As I see it, there is only one dharma ..." (Mahapragya 1983 I:26)

Note how Mahapragya, who knew full well that conversion ${ }_{\mathrm{cc}}$ was forbidden by the Ranas, turns the tables on his accusers by use of the traditional assumption that there is only one dharma, that all religious practice is ultimately the same, therefore there are not 'religions' in the plural.

It was the Ranas who turned the Hindu Dasain (Durga Puja, Dasara) festival into the national festival par excellence. They also developed the custom of holding the pajani during the festival, the ritual in which government post-hold- 
ers were confirmed in their post. If they were not given a turban, they would have to walk home without one, so that everyone would know that they had lost their position. ${ }^{18}$ Today, in the city of Laltipur, the festival of Dasain is almost universally observed. Before 1990 there were only a very few Buddhist lay people-hard-line supporters of the Theravadin monks - who would say, "I'm a Buddhist, I don't observe Dasain." It is true that at the core of the public ritual are animal sacrifices to the goddess Taleju-Durga and the sacralization of royal power (domestically it is a ritual of household solidarity and patriarchal authority). High-caste Buddhists evolved Tantric justifications of the festival, turning it into one of the main occasions in the year for worship in their secret Tantric shrines. In Lalitpur Buddhists also provided the dancers to perform annual dances of the Eight Mother Goddesses, Bhairava, and Ganesha (the Gã Pyakhã) (which have now been discontinued). In this way, just as Hindus participated in the fundamentally Buddhist Bungadyah festival, Buddhists participated fully in Dasain.

By the early twentieth century the Rana regime was beginning to have to cope with the changing expectations, due to religious reformism and the growing nationalist movement in India. The Ranas themselves began to take the first tentative steps towards constructing the country as a nation and its people as more than a collection of communities who happened to be ruled by one king. ${ }^{19}$ Thus, in the later Rana period amendments were made to the law code (though these were published only in 1953 after the fall of the Ranas), which expanded the definition of Hinduism and made the position somewhat clearer: Hindus were explicitly forbidden to convert to Buddhism (no doubt in response to the Mahapragya case). Hindus are defined as followers of Shaivism, Vaishnavism, and Jainism, as well as sects such as the Arya Samaj, Brahmo Samaj, Ramakrishna, Vallabhi, and Ramkabir. Despite this formal recognition of these sects as 'Hindu,' the Ranas were quite as hostile to modernist forms of Hinduism, such as the Arya Samaj-perhaps even more so- than they were to new forms of other religions. Thus Shukra Raj Joshi was hung for belonging to the Arya Samaj in 1941 along with three political revolutionaries (Joshi and Rose 1966:51, 55). The new laws specifically labeled Islam, Christianity, and the Kabir panth as 'irreligious foreign teachings' (vidharmi bidesi mat). Buddhism, though defined as a mat, was not labeled 'irreligious' (contrary to dharma) or 'foreign' (Höfer 1979:160). Conversion ${ }_{\text {cc }}$ of any kind was out, but drifting into Hinduism was encouraged.

The Rana period was the time when the state of Nepal as it is today was con-

18 On the political implications of Dasain, see Krauskopff and Lecomte-Tilouine (1996), PfaffCzarnecka (1996), and Gellner (2001a:ch. 3). On the importance of Dasain for patriarchy and the patrilineage, see Bennett (1983).

19 On the formation of Nepali national identity, see Burghart (1996:ch. 8), Whelpton (1997), and Onta $(1996 ; 1997)$. Chalmers (2003) shows that much of the discourse of Nepali nationalism was first formulated by emigré Nepalis in Banaras and then in Darjeeling, before being taken up by the government of Nepal itself. 
solidated. Numerous local elites began to Hinduize as they sought to maintain links to the center (Pfaff-Czarnecka 1997). Many tribal groups began to adopt the Nepali language. Caste distinctions were written into law and were supported by the full force of the state (Höfer 1979). The state attempted to propagate a basic and minimal Hinduism: respect for the cow (Michaels 1997) and participation in Dasain. In this context Newar Buddhists continued their own traditions, while adapting their outer form to appear as Hindu as possible. This was a situation that already engendered a reform movement as early as the 1920s, when Newar Buddhists, including Mahapragya, adopted Tibetan monasticism. Later he and his companions went on to convert to Theravada Buddhism in India, viewing it as a more effective vehicle with which to reform their own tradition. $^{20}$

\section{THE PANCHAYAT PERIOD (1960-1990)}

After considerable delay and maneuvering, King Mahendra permitted elections to take place in 1959. The Congress Party won an absolute majority of seats and formed a government under B. P. Koirala. After eighteen months Mahendra decided that parties were detrimental to Nepal. He had Koirala and other Congress leaders imprisoned and declared a new system of guided democracy supposedly based on the traditional Nepali (and South Asian) institution of panchayats (local councils). ${ }^{21}$

'Building the nation' under the leadership of the King and developing 'nationalism' were, along with development (vikas), the prime aims of the regime. Nepal was frequently referred to using the phrase ekmatra Hindu rajya, 'the only Hindu kingdom (in the world).' Buddhism, Jainism, and Sikhism were seen as 'branches' of Hinduism, just as they were in modernist Hindu thought in India. This meant that Brahmans could speak for Buddhism, and that Buddhists could legitimately be considered as Hindus. The Buddha, born in Lumbini, just inside the present-day boundary of Nepal with India, was praised in school textbooks, tourist literature, and government speeches as one of the greatest sons of Nepal, and the nearby town of Bhairawaha was renamed Siddharthanagar. Meanwhile the regime gave the bulk of its financial and symbolic support to Hinduism. Links were maintained with the VHP and BJP in India, which were happy to lend their support, in turn, to the last remaining Hindu king (Bouillier 1995). That the king must be "an adherent of Aryan culture and the Hindu religion" was specified in all Nepal's constitutions from that of 1959 to that of 1990 .

This 'domination by subordinate inclusion' was not seen as problematic by the older generation of Buddhists accustomed to the play of inclusion and ex-

20 On the Theravada reform movement, see Kloppenberg (1977), Leve (2002), and LeVine and Gellner (forthcoming).

21 On the Panchayat period and its ideology see Gaborieau (1982), Borgström (1980), Pigg (1992), Gellner (2001b), and Whelpton (2005). 
clusion between Buddhism and Hinduism. They were used to the discourse of commonality and its stress on the 'unity' of Buddhism and Hinduism. Some would even present themselves as Hindus in certain contexts if this was politic or advisable. Most of the younger generation of activists were not at all happy about this official stance on Buddhism, however. They saw it as part of a plot to absorb and eventually extinguish Buddhism. As evidence they cited the gradually declining figures for Buddhists in the census (see Table 2), and the way in which Buddhism had to fight for separate recognition. They did not like having to cooperate with Hindus or having to present a united front with Hindus in order to get government assistance or in order simply to be allowed to develop, and tap into, foreign sources of support for Buddhism (which were, and were perceived to be, substantial). There was some justice in their charge that conversion $_{\text {cc }}$ into Hinduism was condoned and even encouraged by the state, whereas conversion in other directions was strictly forbidden.

The fall of the Rana regime meant the opening of Nepal to the West and, eventually, an influx of foreign aid workers, diplomats, and tourists. It meant the removal of the constraints on Nepalis traveling to India and of Indians coming to Nepal. However, the government was still concerned about the issue of conversion. As in India, it was illegal to provide inducements for conversion. Missionary organizations_-particularly the Jesuits and the UMN (an alliance of Protestant churches) — were permitted to establish schools, hospitals, and aid projects, but they had to give an undertaking not to proselytize. The Summer Institute of Linguistics was allowed to work in Nepal from 1966. Its members carried out pioneering linguistic work and translated the Bible into various languages of Nepal, but in 1976 their ten-year contract was not renewed, and they had to leave the country, presumably on suspicion of proselytizing. Some Christians, both Nepalis and foreigners, were imprisoned on the same charge during the Panchayat period, which caused some controversy abroad (Burghart 1996:297). The self-conscious Hindu identity of the regime meant that censustakers were encouraged to use 'Hindu' as the default option and to assign as many as possible to it. The epigraph cited at the head of this article demonstrates that people in the 1950s had not yet begun to think of themselves as belonging uniquely to one identifiable and countable 'religion.' Buddhists organized, campaigned, and did their best to mobilize international links in order to strengthen themselves against Hindu domination (LeVine and Gellner forthcoming). However, they were careful to restrict their campaigning to groups already defined as Buddhist, and in fact the Theravadins, with rare exceptions, remained dominated by, and restricted their activities to, the Newar community in this period.

THE MULTI-PARTY PERIOD (1990-2002)

In the freer environment after the fall of the Panchayat regime, and taking advantage of the constitutionally guaranteed right of assembly, there has been an 
explosion of non-governmental organizations dedicated to cultural, linguistic, political, social service, and religious purposes. Some Buddhist organizations stand out from the normal pattern in terms of the number of people they can mobilize, the level of their activity, the amount of money they can raise, and the number of international contacts at their disposal. Buddhist organizations are helped in this by the existence of Theravada monasticism. Theravada monasteries and nunneries have grown steadily from 1946 onwards. As strictly religious organizations, they were able to act freely under the Panchayat regime. Today there are approximately eighty monks, over 100 novices, and over 120 nuns. Twenty-nine monasteries and nunneries have been established in Kathmandu district alone and there are others in all the major urban centers of the country and in many villages of the Kathmandu Valley as well. When, in 1990, taking advantage of the new freer political conditions, Buddhist activists started offering the chance to Janajati boys to go to Thailand as monastic novices, there was much negative comment from Brahmans in the press, but nothing was done to prevent it. Buddhism and Hinduism were now separate religions, and it was possible to convert from one to the other.

A key motivation for Buddhist activists is to define themselves as "not Hindu.' In this they anticipated by some years the anti-Hindu ethnic activists who began moves to boycott the Dasain festival after 1990. On the one hand, the rejection of Hinduism is a defensive move, in order to prevent Hindu spokesmen speaking for Buddhism. Such Hindu intellectuals frequently invoke the fact that the Buddha is an incarnation of Vishnu in order to incorporate Buddhism in this way. Theravadin monks have contested this since at least the 1960s, and the rhetoric was certainly very much in the air during my fieldwork in the early $1980 s^{22}$ On the other hand, condemning Hinduism is a core part of the Buddhist revivalists' project to reform the inherited traditions of Newar Buddhists. For the modernists, any religious action that is justified purely on traditional grounds, or that is seen to be motivated by desire for prestige, or for worldly power or instrumental ends, is dismissed as Hindu or due to Hindu influence. Animal sacrifice is a key target of Buddhist reformists, whether modernists or not. Buddhist activists' opposition to the official view of Buddhism as a branch of Hinduism has already been mentioned. It was therefore natural that Buddhist activists should have sought to establish an independent and autonomous existence, and should want a secular Constitution. ${ }^{23}$

While some modern activists' first allegiance is to Buddhism, others are primarily, or only, interested in ethnic issues. There is a considerable overlap between the two groups, but it is certain that for some the two issues are distinct.

22 For the early 1960s, see the pamphlet by Bhikkhu Dharmalok (1965); on the 1980s, see Gellner (1992:93). More generally, see Leve (2002) and LeVine and Gellner (forthcoming).

23 The term that is used is to translate 'secular' is dharma-nirapeksa, literally "religiously nonaligned." 
There are Buddhist activists who are wholly uninterested in ethnic issues, and ethnic activists who have no particular interest in religion except as 'culture. ${ }^{24}$

\section{The 1990 Constitution}

It is one of the bitterest disappointments for the Buddhist activists, as well as for ethnic activists, that the new Constitution of 1990 was not secular but continues to describe Nepal as a Hindu kingdom. In the period leading up to its promulgation there was a huge campaign for a secular constitution which culminated in a demonstration on 30 June 1990 at which organizers claimed to have mobilized over 150,000 people (Gellner 1997:178) though a more sober assessment puts the number at 25,000 to 30,000 (Hoftun et al. 1999:314). The previous day, around 5,000 to 6,000 Hindus had marched in favor of a Hindu constitution (ibid.). On the pro-secular march Buddhists were in the majority, but Christians and others were also present. Muslim organizations, which had been in touch with the activists beforehand, withdrew from the march at the last moment after receiving representations from the Palace. The argument of the Hindus was that the vast majority of the population was Hindu and that therefore the country as a whole should be so recognized. ${ }^{25}$ The argument of the secularists was that designating the kingdom as Hindu would entrench the privileged position of already dominant groups.

The new constitution signaled radical change by designating Nepal 'multiethnic,' 'multi-lingual, ' 'democratic,' and 'Constitutional monarchical.' But the key word 'multi-religious' (bahu-dharmik) was not present. It was a great surprise to ethnic and religious activists that the leaders of the Congress and Communist parties could vote for this, despite previous promises to support a secular constitution. In the case of the Communists, it showed, activists felt, that they were Brahmans first, and Communists a poor second. In the words of the Country Paper on Indigenous People of Nepal, prepared by ethnic activists for the United Nations Year of Indigenous People in 1993:

The Hindu domination begins with the constitution itself. The new constitution, with all its good points in human rights and freedom has been marred at the outset because it declared the country as a Hindu kingdom run according to Hindu constitutional monarchial theories. The Nepali Congress party in power had promised all along that it would support secularism in the constitution. So did the party in opposition. But when the consitutional [sic] drafting committee submitted the constitution to the king for approval, the cabinet composed of representatives from Nepali Congress, United Leftist Front and Royal Palace under the congress Prime Minister K. P. Bhattarai made certain changes in the submitted version and made the kingdom a Hindu kingdom. Thus, many Nepalese people, particularly the indigenous peoples felt that the constitutions [sic] still failed to grasp their aspirations ... (Country 1993:13-14).

\footnotetext{
${ }^{24}$ For more details on Newar ethnic nationalism, see Gellner (1986; 1997; 2003), Shrestha (1999), and Grandin (1989).

25 See Hoftun et al. (1999:315-20) for more on the arguments on both sides. For more on the constitution, see Dhungel et al. (1998).
} 
One version that circulated afterwards, playing perhaps on stereotypes of the crafty Brahman, related how the simple removal of a comma at the last stage meant that instead of it being specified that it was the king who must be a Hin$\mathrm{du}$, it became the whole country.

The Buddhist case against the Hindu constitution is made, among others, in a little booklet, bringing together three newspaper articles from 1991, by Dr Keshab Man Sakya, entitled Hindu Adhirajya, Nepalko Vidambana (Hindu Kingdom: Nepal's Humiliation). The argument is that the golden period for Buddhism was that of the Licchavis, the first Nepali dynasty for which there is a historical record. ${ }^{26}$ In the Malla period the kings became Hindu, "pressurized" their people to be Hindu, and restricted the privilege of being a Kshatriya to those around them. Shresthas were "trapped" into being Hindus. The people welcomed Prithvi Narayan Shah, but his regime gave way to the even more oppressive Ranas who seized Buddhists' land to build their palaces. The Panchayat regime provided encouragement to Hindu extremism and poverty for the people, who were forced to sell their labor abroad. The Hindu Constitution is a kind of trick that makes everyone other than Brahmans second- or third-class citizens. There are some slightly forced comparisons of Marx and the Buddha on religion. Sakya recognizes that the Buddha praised republics and that he also said that a country without a king is like a river without water; the latter is interpreted to refer to need for law and order. Buddhism is democratic, and helps to ensure democratic norms. The Buddha favored republics, but the conclusion is carefully not drawn that Nepal ought therefore to be a republic. (Had the author been writing today, he might well have drawn this conclusion.) Other more aggressive analyses argue that the point of having Nepal as a Hindu kingdom is to advance the program of Hindu fundamentalists in India, to introduce Hindi as the national language, to promote caste differences and feudal inequality, to provide jobs for Brahman boys, and eventually to incorporate Nepal into India (Tuladhar 1992).

With aggressive, modernist understandings of Buddhism like these, we are far from the polytropic world in which the boundary between Buddhism and Hinduism is downplayed and considered relatively insignificant. On the contrary, in one's social and religious practices, as well as in one's political allegiances, to be 'non-Hindu' is of primary importance. Reversing centuries of 'drifting' into Hinduism and simultaneously reinforcing Buddhist identities is the prime task of the Buddhist reformers and activists.

\section{CONCLUSION}

If a nation is a daily plebiscite (as Ernest Renan claimed), so in a sense is religious allegiance. The decision to participate in or owe allegiance to either one,

26 The conventional dates for the Licchavis are from 464 c.E., the year of the first inscription, until 880. It is often assumed by Nepalis that the Licchavi kings of the Kathmandu Valley were related to the Licchavis of north India, who flourished 800 years earlier, but this is by no means certain. 
or both, or neither of the two traditions of Buddhism and Hinduism, whether a collective or an individual decision, is, in that sense, also a daily decision on conversion, or at least on conversion ${ }_{\mathrm{cc}}$.

In terms of the philosophical set of distinctions introduced at the beginning, Ranjit Malla, the King of Bhaktapur, saw the choice set before him by the Capuchin fathers as a form of 'opting' and he presumably judged that to change his religion would involve too much unpredictability for him when he was so preoccupied with other matters (principally warring against the other local kingdoms): he had much to lose by cutting himself off from his traditional religion and no obvious need to convert, hence the offer instead of a group of his subjects to the fathers whom he did not wish to displease. Buddhism was seen at that time, and is still so seen by many, as the hereditary identity of particular groups of people, an identity which is both a part of Hinduism and distinct from it depending on context. Buddhists saw no problem in presenting themselves both as Buddhist and as part of the Hindu world, and still today there are some who continue to think like this. In the Rana and Panchayat periods the state gave strong backing, in the ways indicated above, to the notion that all religions were subordinate forms of Hinduism, or at least could and must, within a Hindu kingdom, be accommodated within a Hindu framework. Discarding a Buddhist identity for a Hindu one was an entirely understandable social process, undertaken by groups that were upwardly mobile or had particular connections to the elite. Such a move was not as momentous as 'opting'; it did not involve a reordering of basic values or irreversible change in one's criteria of assessment. For some tribal groups, who are today known as Janajati, the gradual adoption of Hindu ways was, as indicated above, incremental and almost unnoticed-a case of 'drifting' into Hinduism. Activists from these groups have succeeded in reversing this trend, as is clearly shown by their success in getting the category 'Kiranti' accepted as a type of religion in the 1991 census, and the dramatic half-a-million jump in the number of people being assigned to it in 2001. Nonetheless, large numbers of Janajati people still consider themselves Hindu and are returned as such in the census. ${ }^{27}$ The state's ban on proselytizing and its hostility to conversion away from Hinduism were an admission, from early on, of the vulnerability of Hindu dominance and the polytropic view to religions that demanded exclusive allegiance.

In the 1930s traditional Newar Buddhism began to be seen by a few reformers as inauthentic. They started the movement to recapture the practice of lifelong celibacy. Inevitably, this moved the emphasis away from ritual and away from sacralizing traditional social units. Eventually the Theravada movement became the principal vehicle for Buddhist modernism within Nepal (LeVine and Gellner forthcoming). The switch from viewing Buddhism in the traditional way to accepting a modernist interpretation was for many individuals a case of

${ }^{27}$ Current estimates put the proportion of Janajatis in the total population at around 42 percent. As Table 2 shows, despite campaigning by activists, 80 percent of Nepalis were still returned as 'Hindu' in the 2001 census. 
conversion $_{\mathrm{sp}}$ : that is, a compulsive and radical change of perspective after which one's former life is viewed as morally wrong. This is the phenomenon that Geertz called 'internal conversion' (Geertz 1973:ch. 7). And it is what Horton was pointing to when he insisted that the appearance of Islam and Christianity were "catalysts-i.e. stimulators and accelerators of changes which were 'in the air' anyway; triggers for reactions in which they do not always appear amongst the end-products" (Horton 1971:104). The reworking of Buddhist identity that began in the 1930s and took off in a big way in the 1950s marked a decisive break in terms of Buddhism's relation to Hinduism. The catalyst was, broadly, the Western view of religion as a single, overarching religious identity recorded unambiguously in a census, which is different from, and equal to, all other similar identities. Despite the fact that the official view of the Panchayat regime was that Buddhism, Sikhism, and Jainism were branches of Hinduism, at least in the context of the census its ideologues never questioned this basic modernist tenet of unique and exclusive religious attachment.

\section{REFERENCES}

Allen, N. J. 1997. Hinduization: The Experience of the Thulung Rai. In, D. N. Gellner, J. Pfaff-Czarnecka, and J. Whelpton, eds., Nationalism and Ethnicity in a Hindu Kingdom: The Politics of Culture in Contemporary Nepal. Amsterdam: Harwood Academic Publishers, 303-23.

Alsop, I. 1996. Christians at the Malla Court: The Capuchin "Piccolo Libro." In, S. Lienhard, ed., Change and Continuity: Studies in the Nepalese Culture of the Kathmandu Valley. Alessandria: Edizioni dell'Orso/CESMEO, 123-35.

Barth, F. 1969. 'Introduction.' In, F. Barth, ed., Ethnic Groups and Boundaries. Bergen: Universitets Forlaget, 9-38.

Bennett, L. 1983. Dangerous Wives and Sacred Sisters: Social and Symbolic Worlds of High-Caste Women in Nepal. New York: Columbia University Press.

Borgström, B. E. 1980. The Patron and the Pancha: Village Values and Panchayat Democracy in Nepal. New Delhi: Vikas.

Bouillier, V. 1995. Du bon usage des Brahmanes: Les Bahun et l'état népalais. Journal Asiatique 283, 2:445-68.

Brekke, T. 2003. Conversions in Buddhism? In, R. Robinson and S. Clarke, eds., Religious Conversion in India: Modes, Motivations, and Meanings. Oxford University Press: Delhi, 181-91.

Brinkhaus, H. 1996. Tolerance and Syncretism in the Religious History of the Kathmandu Valley. In, S. Lienhard, ed., Change and Continuity: Studies in the Nepalese Culture of the Kathmandu Valley. Alessandria: Edizioni dell'Orso/CESMEO, 137-47.

Burghart, R. 1996. The Conditions of Listening: Essays on Religion, History and Politics in South Asia. C. J. Fuller and J. Spencer, eds. Delhi: Oxford University Press.

Carrithers, M. 2000. On Polytropy: Or the Natural Condition of Spiritual Cosmo-politanism in India: The Digambar Jain Case. Modern Asian Studies 34, 4:831-61.

Chalmers, R. 2003. “'We Nepalis': Language, Literature and the Formation of a Nepali Public Sphere in India, 1914-1940.” Ph.D. thesis, School of Oriental and Asian Studies, London.

Country. 1993. Country Paper on Indigenous Peoples of Nepal. Kathmandu: The National Committee for the International Year (1993) for the World's Indigenous Peoples, Nepal. 
Dharmalok Mahasthabir, Bhikkhu. 1965. Buddha's Doctrine of Universal Flux, Whose Religion is True, and Answers to Five Questions Raised by Hemraj Timilsina Shar$m a$. Kathmandu: self-published.

Dhungel, S.P.S., B. Adhikari, B. P. Bhandari, and C. Murgatroyd. 1998. Commentary on the Nepalese Constitution. Kathmandu: DeLF.

Douglas, W. 2002. 'The Fifteenth-Century Re-Invention of Nepalese Buddhism.' D.Phil. thesis, University of Oxford.

Dumont, L. 1960. World Renunciation in Indian Religions. Contributions to Indian Sociology 4:33-62. (Repr. in L. Dumont 1980, Homo Hierarchicus. Chicago: University of Chicago Press, 267-86.)

Fisher, H. J. 1973. Conversion Reconsidered: Some Historical Aspects of Religious Conversion in Black Africa. Africa 43:27-40.

- 1985. The Juggernaut's Apologia. Africa 55:153-73.

Fisher, W. F. 2001. Fluid Boundaries: Forming and Transforming Identity in Nepal. New York: Columbia University Press.

Flood, G. 2003. Introduction: Establishing the Boundaries. In, G. Flood, ed., The Blackwell Companion to Hinduism. Oxford: Blackwell.

Gaborieau, M. 1982. Les rapports de classe dans l'idéologie officielle du Népal. Purusartha $6: 251-90$.

Gaenszle, M. 1997. Changing Concepts of Ethnic Identity among the Mewahang Rai. In, D. N. Gellner, J. Pfaff-Czarnecka, and J. Whelpton, eds., Nationalism and Ethnicity in a Hindu Kingdom: The Politics of Culture in Contemporary Nepal. Amsterdam: Harwood Academic Publishers, 351-73.

Geertz, C. 1973. The Interpretation of Cultures: Selected Essays. New York: Basic Books.

Gellner, D. N. 1986. Language, Caste, Religion, and Territory: Newar Identity Ancient and Modern. European Journal of Sociology 26:102-48.

- 1992. Monk, Householder, and Tantric Priest: Newar Buddhism and Its Hierarchy of Ritual. Cambridge: Cambridge University Press.

- 1996. A Sketch of the History of Lalitpur (Patan) with Special Reference to Buddhism Contributions to Nepalese Studies 23, 1:125-57.

1997. Caste, Communalism, and Communism: Newars and the Nepalese

State.' In, D. N. Gellner, J. Pfaff-Czarnecka, and J. Whelpton, eds., Nationalism and Ethnicity in a Hindu Kingdom: The Politics of Culture in Contemporary Nepal. Amsterdam: Harwood Academic Publishers, 151-84.

. 2001a. The Anthropology of Buddhism and Hinduism: Weberian Themes. Delhi: Oxford University Press.

2001b. From Group Rights to Individual Rights and Back: Nepalese Struggles with Culture and Equality. In, J. Cowan, M. Dembour, and R. Wilson, eds., Culture and the Anthropology of Rights. Cambridge: Cambridge University Press, 177-200. 2003. From Cultural Hierarchies to a Hierarchy of Multiculturalisms: The Case of the Newars of Nepal. In, M. Lecomte-Tilouine and P. Dolfuss, eds., Ethnic Revival and Religious Turmoil in the Himalayas. Delhi: Oxford University Press, 73-131.

. Forthcoming. Public Order, Inclusion, Hybridity: Preconditions of Democracy in Nepal. In, D. Thapa, ed., Inclusion and Democracy in Nepal. Lalitpur: Himal Books.

Gellner, D. N. and D. Quigley, eds., 1995. Contested Hierarchies: A Collaborative Ethnography of Caste among the Newars of the Kathmandu Valley, Nepal. Oxford: Clarendon.

Gombrich, R. F. 1988. Theravada Buddhism: A Social History from Ancient Benares to Modern Colombo. London: Routledge. 
Grandin, I. 1989. Music and Media in Local Life: Music Practice in a Newar Neighbourhood in Nepal. Linköping: Linköping University, Sweden.

Grapard, A. G. 1992. The Protocol of the Gods: A Study of the Kasuga Cult in Japanese History. Berkeley: University of California Press.

Gurung, H. 1998. Nepal: Social Demography and Expressions. Kathmandu: New Era. . 2003. Social Demography of Nepal: Census 2001. Lalitpur: Himal Books.

Gutschow, N. 1982. Stadtraum und Ritual der Newarischen Städte im Kathmandu-Tal: Eine architektur-anthropologische Untersuchung. Stuttgart: Kohlhammer.

Halbfass, W. 1988. India and Europe: An Essay in Understanding. Albany: State University of New York Press.

Hefner, R. 1993. Introduction: World-Building and the Rationality of Conversion. In, R. Hefner, ed., Conversion to Christianity: Historical and Anthropological Perspectives on a Great Transformation. Berkeley: University of California Press, 3-44.

Höfer, A. 1979. The Caste Hierarchy and the State in Nepal: A Study of the Muluki Ain of 1854. Innsbruck: Universitätsverlag Wagner.

Hoftun, M., W. Raeper, and J. Whelpton. 1999. People, Politics and Ideology: Democracy and Social Change in Nepal. Kathmandu: Mandala Book Point.

Horton, R. 1971. African Conversion. Africa 41:85-108. . 1975. On the Rationality of Conversion. Africa 45:219-35, 373-99.

Ikenga-Metuh, E. 1987. The Shattered Microcosm: A Critical Survey of Explanations of Conversion in Africa. In, K. Holst Petersen, ed., Religion, Development and African Identity. Uppsala: Scandinavian Institute of African Studies, 11-27.

Joshi, M. B. and L. Rose. 1966. Democratic Innovations in Nepal: A Case Study of Political Acculturation. Berkeley: University of California Press.

Kloppenberg, R. 1977. Theravada Buddhism in Nepal. Kailash 5, 4:301-21.

Krauskopff, G. and M. Lecomte-Tilouine, eds. 1996. Célébrer le pouvoir: Dasai, une fête royale au Népal. Paris: Centre National de la Recherche Scientifique.

Leve, L. 2002. Subjects, Selves, and the Politics of Personhood in Theravada Buddhism in Nepal. Journal of Asian Studies 61, 3:833-60.

Lévi, S. 1905. Le Népal: étude historique d'un royaume hindou (3 vols.). Paris: Leroux. (Reissued 1991, Delhi: Asian Educational Services.)

LeVine, S. and D. N. Gellner. Forthcoming. Rebuilding Buddhism: The Theravada Movement in Twentieth-Century Nepal. Cambridge, Mass.: Harvard University Press.

Levy, R. I. (with K. Rajopadhyaya). 1990. Mesocosm: Hinduism and the Organization of a Traditional Newar City in Nepal. Berkeley: University of California Press.

Lewis, T. T. 2000. Popular Buddhist Texts from Nepal: Narratives and Rituals of Newar Buddhism. Albany: SUNY Press.

Locke, J. 1980. Karunamaya: The Cult of Avalokitesvara-Matsyendranath in the Valley of Nepal. Kathmandu: Sahayogi.

Lorenzen, D. N. 1999. Who Invented Hinduism? Comparative Studies in Society and History 41, 4:630-59.

Mahapragya 1983 (3 vols.: 1983, 1995, 1998). Sāhityasutā karmasthānācārya wa bauddharsi Mahāprajñāyā ātmakathā (An Autobiography of Mahaprajna, the First Theravadi Bhikshu of Modern Nepal), D. Newami, trans. and ed. Rishi Ashram, Kathmandu: Sakalopasika.

Messerschmidt, D. and N. J. Gurung. 1974. Parallel Trade and Innovation in Central Nepal: The Case of the Gurung and Thakali Subbas Compared. In, C. von FürerHaimendorf, ed., Contributions to the Anthropology of Nepal. Warminster: Aris and Phillips, 197-221.

Meyer, B. 1996. Modernity and Enchantment: The Image of the Devil in Popular African Christianity. In, P. van der Veer, ed., Conversion to Modernities: The Globalization of Christianity. New York and London: Routledge, 199-230. 
Michaels, A. 1997. The King and the Cow: On a Crucial Symbol of Hinduization in Nepal. In, D. N. Gellner, J. Pfaff-Czarnecka, and J. Whelpton, eds., Nationalism and Ethnicity in a Hindu Kingdom: The Politics of Culture in Contemporary Nepal. Amsterdam: Harwood Academic Publishers, 79-99.

2004. Hinduism, Past and Present, B. Harshav, trans. Princeton: Princeton University Press.

Onta, P. 1996. Creating a Brave Nepali Nation in British India: The Rhetoric of Jati Improvement, Rediscovery of Bhanubhakta and the Writing of Bir History. Studies in Nepali History and Society 1, 1:37-76.

1997. Activities in a 'Fossil State': Balkrishna Sama and the Improvisation of Nepali Identity. Studies in Nepali History and Society 2, 1:69-102.

Owens, B. M. 1989. "The Politics of Divinity in the Kathmandu Valley: The Festival of Bungadya/Rato Matsyendranath.” Ph.D. dissertation, Columbia University.

. 2000. Envisioning Identity: Deity, Person, and Practice in the Kathmandu Valley. American Ethnologist 27, 3:702-35.

Peel, J.D.Y. 1977. Conversion and Tradition in Two African Societies: Ijebu and Buganda. Past and Present 77:108-41.

. 1990. The Pastor and the Babalawo: The Interaction of Religions in Nineteenth-Century Yorubaland. Africa 60:338-69.

Petech, L. 1984. Mediaeval History of Nepal (c. 750-1482). Rome: ISMEO.

Pfaff-Czarnecka, J. 1996. A Battle of Meanings: Commemorating Goddess Durga's Victory over the Demon Mahisa as a Political Act. Kailash 18, 3-4:57-92.

. 1997. Vestiges and Visions: Cultural Change in the Process of Nation-Building in Nepal. In, D. N. Gellner, J. Pfaff-Czarnecka, and J. Whelpton, eds., Nationalism and Ethnicity in a Hindu Kingdom: The Politics of Culture in Contemporary Nepal. Amsterdam: Harwood Academic Publishers, 419-70.

Pigg, S. L. 1992. Inventing Social Categories through Space: Social Representations of Development in Nepal. Comparative Studies in Society and History 34:491-593.

Quigley, D. 1996. Social Mobility and Social Fragmentation in the Newar Caste System. In, S. Lienhard, ed., Change and Continuity: Studies in the Nepalese Culture of the Kathmandu Valley. Alessandrio: Edizioni dell'Orso/CESMEO, 69-84.

Robinson, R. and S. Clarke, eds. 2003. Religious Conversion in India: Modes, Motivations, and Meanings. Delhi: Oxford University Press.

Rosser, C. 1966. Social Mobility in the Newar Caste System. In, C. von Fürer-Haimendorf, ed., Caste and Kin in Nepal, India and Ceylon. Bombay: Asia Publishing House, $68-139$.

Sakya, K. M. 1991. Hindu Adhirajya, Nepalko Vidambana (Hindu kingdom: Nepal's humiliation) [in Nepali]. Kathmandu: Yuva Bauddha Samuha.

Shrestha, B. G. 1999. The Newars: The Indigenous Population of the Kathmandu Valley in the Modern State of Nepal. Contributions to Nepalese Studies 26, 1:83-117.

Srinivas, M. N. 1956. A Note on Sanskritization and Westernization. Journal of Asian Studies (Far Eastern Quarterly) 15, 4:481-96.

Staal, F. 1963. Sanskrit and Sanskritization. Journal of Asian Studies 23, 3:26-75.

Toffin, G. 1984. Société et religion chez les Néwar du Népal. Paris: Centre National de la Recherche Scientifique.

- 1993. Le Palais et Le Temple: Le Fonction Royale dans la Vallée de Népal. Paris: Centre National de la Recherche Scientifique.

Tuladhar, Y. R. 1992. Nepal's Misfortune, the Unequal Treaty and Brahmanism. Kathmandu: Rosan Ratna Tuladhar.

Ullmann-Margalit, E. 1985. Opting: The Case of 'Big' Decisions. In, P. Wapnewsky, ed., Yearbook of the Institute of Advanced Study, Berlin. Berlin: Wissenschaftskolleg, 441-54. 
Vajracharya, A. K. 1980 (VS 2037). Bungadyo Nepale Hahgu Khã (The story of how Bungadyo was brought to Nepal) [in Nepal Bhasha]. Lalitpur: self-published.

Van der Veer, P. 1994. Religious Nationalism: Hindus and Muslims in India. Berkeley: University of California Press.

Viswanathan, G. 1998. Outside the Fold: Conversion, Modernity and Belief. Princeton: Princeton University Press.

Von Stietencron, H. 1997. Hinduism: On the Proper Use of a Deceptive Term. In, G.-D. Sontheimer and H. Kulke, eds., Hinduism Reconsidered. Delhi: Manohar.

Whelpton, J. 1991. Kings, Soldiers and Priests: Nepalese Politics, 1830-1857. Delhi: Manohar.

1997. Political Identity in Nepal: State, Nation and Community. In, D. N. Gellner, J. Pfaff-Czarnecka, and J. Whelpton, eds., Nationalism and Ethnicity in a Hindu Kingdom: The Politics of Culture in Contemporary Nepal. Amsterdam: Harwood Academic Publishers, 39-78.

. 2005. A History of Nepal. Cambridge: Cambridge University Press. 